\title{
Security Tokens and the Future of EU Securities Law: Rethinking the Harmonisation Project
}

\begin{abstract}
This article investigates the missing legal dimension in European Commission's digital finance strategy; namely, rules for holding, transferring, and collateralising digital financial assets known as security tokens, as well as their treatment in insolvency. The lack of EU rules would expose future token holders to a patchwork of unpredictable and inconsistent Member State laws and further fragment the private law underpinnings of EU capital markets. The article argues that digital transformation presents an opportunity for securities law harmonisation that the EU should not miss. At the same time, the EU needs to rethink its prevailing approach to harmonisation, which has ignored transparent holding systems. Three key issues for future EU securities law will be discussed: first, disintermediation fits poorly with the current conflict of laws acquis based on the so-called Place of the Relevant Intermediary (PRIMA) approach. The article nevertheless argues for preserving a modified PRIMA rule rule as an option in order to support market integration and competition. Second, future holding systems must be able to accommodate different market needs, including those of the securities financing market where liquidity is valued over control. This underlines the continuing relevance of intermediated securities law. Finally, as a first step towards more comprehensive harmonisation of substantive rights, the article presents a modest proposal for protecting the rights of token holders in insolvencies.
\end{abstract}

Keywords: Security tokens, blockchain, EU law, harmonisation, securities law

\section{Table of Contents}

1 Introduction -254

2 Disintermediation of Securities Holding Systems -258

2.1 The Promise of Distributed Ledger Technology — 258

2.2 The Digital Finance Package and "DLT Market Infrastructures" - 262

3 The Case and Opportunity for Private Law Harmonisation 265

Heikki Marjosola, Associate Professor of Financial Law, Faculty of Law, University of Helsinki. Email: heikki.marjosola@helsinki.fi. I would like to thank Emilios Avgouleas, Eva Micheler and Rainer Kulms for helpful comments and suggestions.

Ә OpenAccess. (C) 2022 Heikki Marjosola, published by De Gruyter. (cc))BY-NC-ND This work is licensed under the Creative Commons Attribution-NonCommercial-NoDerivatives 4.0 International License. 
3.1 Legal Uncertainty on Substantive Rights and Applicable Law 265

3.2 The Opportunity for Private Law Harmonisation 267

3.3 Disintermediated Systems and Securities Law Harmonisation

4 Elements of EU Security Tokens Law — 271

4.1 Which Conflict of Laws Rule for Security Tokens and Direct Holding Systems? 271

4.2 Intermediated Access to DLT Market Infrastructures 275

4.3 A Modest Proposal for Substantive Harmonisation 277

5 Conclusions -279

\section{Introduction}

Although the hubris around blockchains, smart contracts and other FinTech buzzwords has given way to reality checks, the number of new digital financial assets, as well as platforms, brokers, custodians and other intermediaries trading and safekeeping those assets, has continued to grow. ${ }^{1}$ The expansion of the new digital financial space might be quick and unpredictable, especially in payments. ${ }^{2}$ The boundary between the token economy and the traditional financial system is also blurring; institutional interest and adoption of digital assets is growing ${ }^{3}$ and more crypto firms and infrastructures are being licensed to offer financial services through regulatory sandboxes and FinTech Hubs. ${ }^{4}$

However, digital disruption has gained less momentum in capital markets. Despite significant interest in using distributed ledger technology (DLT) to issue securities (Security Token Offerings, STOs) $)^{5}$ or to tokenise existing (book

1 See, e.g., PWC, 6thICO / STO Report, A Strategic Perspective, Spring 2020 edition (PWC Report).

2 Tobias Adrian/Tommaso M. Griffoli, The Rise of Digital Money, FinTech Notes No. 19/001, IMF 2019.

3 According to a recent report, more than a third of institutional investors surveyed invest in digital assets. See Fidelity Digital Assets, The institutional investors digital asset survey, 2020 Review (by Ria Bhutoria), June 2020.

4 See A. Blandin et al, 3rd Global Cryptoasset Benchmarking Study, University of Cambridge, Judge Business School, the Cambridge Centre for Alternative Finance (CCAF), September 2020 (3rd Global Cryptoasset Benchmarking Study). See also Kulms in this volume.

5 A distinction is sometimes drawn between DLT-native security tokens and tokenised securities that also exist outside DLT. See OECD, The Tokenisation of Assets and Potential Implications for Financial Markets, OECD Blockchain Policy Series, 2020 available at www.oecd.org/finance/TheTokenisation-of-Assets-and-Potential-Implications-for-Financial-Markets.htm accessed 4 March 2021 (OECD report), p. 15. A similar distinction has been drawn between off-platform asset tokens and on-platform asset tokens. See Financial Market Law Committee (FMLC), Distributed Ledger Technology and Governing Law: Issues of Legal Uncertainty, March 2018, available at www.fmlc.org accessed 4 March 2021 (FMLC report), p. 8. 
entry or physical) securities ${ }^{6}$ the market has remained marginal, especially in Europe. $^{7}$ The technology itself faces challenges regarding e.g. scalability and interoperability $^{8}$ but the primary hurdle is legal: unlike many other crypto-assets that have benefited from regulatory lags and gaps, security tokens qualify prima facie as transferable investment securities. This means that they must comply with the plethora of regulation concerning securities issuance, trading, post-trading, and investor protection. Indeed, STOs are primarily designed to be securities lawcompliant and marketed as such. ${ }^{9}$

Digital finance plays a key role in the European Union's (EU) new industrial strategy. ${ }^{10}$ There has been no shortage of official documents highlighting legal obstacles to tokenisation in Europe and calling for path-clearing legislative action. ${ }^{11}$ Finally, in September 2020, the European Commission released a Digital Finance Package including a new digital finance strategy and a set of legislative proposals aiming to embrace the transformative potential of digital finance. ${ }^{12} \mathrm{~A}$

6 A recent $O E C D$ report identifies tokenisation of securities "as the sector with the most imminent potential for growth.” OECD report (ibid.), p. 13.

7 Commission Staff Working Document, Impact Assessment accompanying the document Proposal for a Regulation of the European Parliament and of the Council on Markets in Crypto-assets and amending Directive (EU) 2019/1937, 24 September 2020, SWD(2020) 380 final 24, p. 29 (MiCA Impact assessment, 24). See also PWC Report (fn. 1), which shows that USA, Singapore, Hong Kong and UK dominate the global market for token offerings.

8 OECD report (fn. 5), p. 19.

9 OECD report (fn. 5), p. 13. In contrast, Initial Coin Offerings (ICOs) have been typically structured to avoid securities regulations. See Clifford Chance, Security Token Offerings - A European Perspective on Regulation. October 2020, 5, available at https://www.cliffordchance.com/con tent/dam/cliffordchance/briefings/2020/10/security-token-offerings-a-european-perspective-onregulation.pdf accessed 4 March 2021.

10 Communication from the Commission, A New Industrial Strategy for Europe COM/2020/102 final.

11 See, e.g., European Parliament, Report on FinTech: the influence of technology on the future of the financial sector, Committee on Economic and Monetary Affairs, Rapporteur: Cora van Nieuwenhuizen (2016/2243(INI), 28 April 2017; EUCO 14/17, CO EUR 17, CONCL 5, 19 October 2017); European Commission, FinTech Action Plan: for a more competitive and innovative European financial sector, 8 March 2018, $\operatorname{COM(2018)~} 109$ final. See also two expert group reports charting venues for regulatory intervention: Final Report of the High Level Forum on the Capital Markets Union, A new Vision for Europe's capital markets, June 2020, p. 74-76 and Expert Group on Regulatory Obstacles to Financial Innovation (ROFIEG), 30 Recommendations on Regulation, Innovation and Finance - Final Report to the European Commission, December 2019.

12 Communication from the Commission on a Digital Finance Strategy for EU, 24 September 2020, $\operatorname{COM}(2020)$ 591. On balance, the package also addresses risks such as fraud, market manipulation, and money laundering, which have been salient features of the new digital markets. See European Securities and Markets Authority (ESMA), The Distributed Ledger Technology Ap- 
proposal for a Regulation for Markets in Crypto-assets (MiCA) would introduce common rules for the thus far unregulated part of the crypto-asset market ${ }^{13}$ while another proposal for a Regulation on a pilot regime for market infrastructures based on distributed ledger technology ("DLT Pilot regime") ${ }^{14}$ is designed specifically for crypto-assets that qualify as financial instruments under the MiFID II framework. ${ }^{15}$ The DLT Pilot regime would in effect establish an EU sandbox - the first of its kind ${ }^{16}$ - for experimenting in and facilitating the development of DLT-based infrastructures for capital markets.

Adoption of the Digital Finance Package would support the creation of markets for security tokens. The proposed rules would enhance legal certainty by explicitly extending the scope of regulation to securities issued in token form, whereas the DLT Pilot Regime would enable offsetting and adjusting the rules nationally where necessary. By allowing Member States to tailor their regulatory frameworks for individual DLT market infrastructures, the pilot regime would support local financial innovation and enhance the competitiveness of EU capital markets. The package would also promote cross-border marketability of security tokens by introducing a Union-wide passport system, thus expanding funding opportunities for European SMEs.

However, the Digital Finance Package does not address the legal uncertainties concerning the rights of security token holders. It includes no initiatives with

plied to Securities Markets, February 2017; ESMA, Report with advice on Initial Coin Offerings and Crypto-Assets, ESMA50 -157-1391, 9 January 2019 (ESMA Advice); European Banking Authority, Report with Advice for the European Commission on Crypto-assets, January 2019; European Parliament, Report with recommendations to the Commission on Digital Finance: emerging risks in crypto-assets - regulatory and supervisory challenges in the area of financial services, institutions and markets (2020/2034(INL).

13 Proposal for a Regulation of the European Parliament and of the Council on Markets in Crypto-assets, and amending Directive (EU) 2019/1937, 24 September 2020, COM(2020) 593 final (MiCA proposal).

14 Proposal for a Regulation of the European Parliament and of the Council on a pilot regime for market infrastructures based on distributed ledger technology, 24 September 2020, COM/ 2020/594 final. In addition, the package includes a proposal for digital operational resilience (Proposal for a Regulation of the European Parliament and of the Council on digital operational resilience for the financial sector.

15 More specifically, financial instruments qualifying as transferable securities admitted to trading or traded on a trading venue, as defined in Article 4(1)(44) of MiFID II. Directive 2014/65/EU of the European Parliament and of the Council of 15 May 2014 on markets in financial instruments and amending Directive 2002/92/EC and Directive 2011/61/EU.

16 Wolf-Georg Ringe/Christoph Ruof, The DLT Pilot Regime: An EU Sandbox, at Last! Oxford Business Law Blog, 19 November 2020, available at https://www.law.ox.ac.uk/business-lawblog/blog/2020/11/dlt-pilot-regime-eu-sandbox-last accessed 4 March 2021. 
regard to holding, transferring, safekeeping, and collateralising security tokens or their treatment in insolvencies. Moreover, neither the EU legislation in force nor the proposed Union legislation help determine with certainty which national law governs such proprietary aspects of security tokens. Leaving these issues for Member States (while introducing a passport to operate freely within the single market) seems surprising given the numerous examples of failed crypto custodians and outdated national legal regimes failing to provide even basic legal protection for clients of bankrupt crypto custodians. ${ }^{17}$ The omission is more understandable, however, if viewed against the historical travails of harmonising general securities law in the EU, an exercise of notorious complexity and political sensitivity. Even as long as twenty years ago, the absence of a common legal framework for holding, acquiring and disposing of securities, and the uneven application of national conflict-of-laws rules regarding securities, were identified as significant legal barriers to integration of EU capital markets. ${ }^{18}$ In 2015, the Commission's Capital Market Union (CMU) strategy restated yet again the need for securities law harmonisation. ${ }^{19}$ However, little progress has been achieved and no legislative initiatives are currently in the pipeline. Existing EU securities law therefore remains restricted in scope, piecemeal, and inconsistent in substance. ${ }^{20}$ Core conceptual issues, such as the legal nature of a security (or a securities account), and the legally recognised techniques of possession and dispossession of a security, remain matters to be determined by Member State law.

One might therefore excuse the EU legislator for leaving these contentious policy issues out of the Digital Finance Package - a controversial initiative in its own right. ${ }^{21}$ This article nevertheless argues that digital transformation pres-

17 For a discussion of nascent case law, see Kulms in this issue; Matthias Haentjens/Tycho de Graaf/Ilya Kokorin, "The Failed Hopes of Disintermediation: Crypto-Custodian Insolvency, Legal Risks and How to Avoid Them”. Singapore Journal of Legal Studies (2020), p. 526. From the perspective of Bitcoin case law, see Janis Sarral/Louise Gullifer QC (Hon), "Crypto-claimants and bitcoin bankruptcy: Challenges for recognition and realization”, Int'l Insolvency Rev. 28 (2019), p. 233.

18 The Giovannini Group, Cross-border Clearing and Settlement Arrangements in the European Union, November 2001.

19 Commission Communication, Action Plan on Building a Capital Markets Union, 30 September 2015, $\operatorname{COM}(2015) 468$ final, and Commission Communication on the Mid-Term Review of the Capital Markets Union Action Plan, 8 June 2017, COM(2017) 292 final.

20 A recent comprehensive review, in the footsteps of the Giovannini Group, appears in European Post Trade Forum Report, 15th May 2017 (EPTF report), available at https://ec.europa.eu/ info/publications/170515-eptf-report_en accessed 4 March 2021.

21 For a brief discussion on reasons why legislative action in this area is unlikely, see Philipp Paech, "Securities, intermediation and the blockchain: an inevitable choice between liquidity and legal certainty?” Uniform Law Review 21 (2016), p. 612, p. 612-613. 
ents a novel opportunity for private law harmonisation that the EU should not miss. First, many of the reasons that have complicated securities law harmonisation so far are either idiosyncratic to intermediated securities or not (yet) present in the case of security tokens. ${ }^{22}$ Second, failing to act would add a further layer of legal complexity and uncertainty to the colourful patchwork of European securities laws. Indeed, DLT-based securities holding systems and tokenisation have already prompted uncoordinated legal action in several Member States. ${ }^{23}$ Finally, DLT-facilitated disintermediation of securities holding systems presents novel problems in terms of legal certainty that require rethinking the philosophy of harmonisation projects for intermediated securities - particularly their difficult relationship with so-called transparent holding systems.

The article is structured as follows: the next section briefly discusses distributed ledger technology and its central promise of eliminating intermediaries and making the financial system more transparent. The third section identifies the missing private law dimension of the Digital Finance Package and makes the case for further harmonisation. The fourth section discusses three key concerns for future EU securities law: the need to update the existing conflict of laws acquis regarding intermediated securities; the continuing relevance of intermediated securities law and the need for future holding systems to accommodate different market needs; and finally the need to protect the rights of token holders in insolvencies as a first step towards more comprehensive substantive harmonisation. The fifth section concludes.

\section{Disintermediation of Securities Holding Systems}

\subsection{The Promise of Distributed Ledger Technology}

In modern, intermediated, securities holding systems one or more intermediaries (i.e., firms offering safekeeping, administration and other securities services) disconnect issuers from investors. In most holding systems risk-bearing investors

22 Apart from the EU, two international securities conventions have been completed: The 2009 UNIDROIT Convention on Substantive Rules for Intermediated Securities (Geneva securities convention) and the 2006 Hague Convention on the Law Applicable to Certain Rights in Respect of Securities held with an Intermediary. Neither of the conventions has entered into force. The Hague convention has been ratified by three countries (The United States, Mauritius and Switzerland) and the Geneva securities convention by one country (Bangladesh).

23 See Kulms in this volume; MiCA Impact Assessment (fn. 7); Clifford Chance report (fn. 9). 
are not identified at Central Securities Depositories (CSD), where CSD participants acting as nominees hold client securities in a pooled form on so-called omnibus CSD accounts. ${ }^{24}$ The intermediated holding structure has evolved to facilitate post-trade clearing and settlement of securities transactions and it provides specific efficiency gains, e.g. by minimising the number of accounts and transactions at the topmost tiers of the holding chain (thus allowing net settlement). ${ }^{25}$ However, the intermediated system also imposes diverse legal risks and costs on market participants. Although modern securities laws generally provide investors with proprietary or quasi-proprietary rights that enjoy priority in the event of a custodian's bankruptcy, the substance of these rights varies among jurisdictions and their effectiveness may be compromised, especially in cross-border situations. ${ }^{26}$ Additionally, to exercise their personal rights related to securities, investors must act through their account-providing intermediary, who may, in turn, have to rely on the relevant intermediary next up the custody chain, and so on. This "no-look-through" principle, whereby each party in the custody chain has rights against their own counterparty but not beyond, remains a cornerstone of - especially Anglo-American - securities law. ${ }^{27}$ Whilst the principle brings several efficiency benefits, it also complicates enforcement of investor rights and corporate governance. ${ }^{28}$

24 Identification of investors at the level of CSD is internationally exceptional, but in some countries it is possible while in some others, as in Finland, mandatory. Such systems are sometimes called transparent because the client's ownership is identifiable on the level of CSD. See section 4.1 below.

25 Clearing and settlement comprise post-trade processes which together ensure the conclusion of a securities transaction, i.e., executing transfer or delivery of securities against payment (delivery and payment together constituting the settlement phase). See, e. g., Charles W. Mooney Jr, "Beyond Intermediation: A New (FinTech) Model for Securities Holding Infrastructures." University of Pennsylvania Journal of Business Law 22 (2019), p. 386, p. 399-401.

26 See e. g. Mooney, ibid, p. 404; Eva Micheler, "Custody chains and asset values: why cryptosecurities are worth contemplating.” The Cambridge Law Journal, 2015, p. 505-533; Eva Micheler, Transfer of Intermediated Securities and Legal Certainty, in: Thomas Keijser (ed.), Transnational securities law, 2014; Luc Thévenoz, "Intermediated Securities, Legal Risk, and the International Harmonization of Commercial Law", Stanford Journal of Law, Business and Finance 13 (2008), p. 384.

27 Joanna Benjamin/Louise Gullifer, Stewardship and Collateral: The Advantages and Disadvantages of the No Look-Through System, in: Louise Gullifer/Jennifer Payne (eds.), Intermediation and Beyond, 2019, p. 223; The Law Commission, Intermediated securities: who owns your shares? A Scoping Paper, 11 November 2020, p. 83.

28 For a recent review from the perspective of the United Kingdom, see the Law Commission, ibid. For a discussion on recent British case law documenting the (sometimes tragic) consequences of intermediation, see Eva Micheler, Intermediated Securities from the Perspective of Invest- 
The onset of DLT has introduced a new dimension to the holding system debate. The technology promises to solve some, if not all, of the problems of intermediated holding without compromising much of its benefits. Blockchains and other DLTs combine existing and new database technology and cryptography to facilitate value transfers over a distributed database, maintained and operated by a network of computers. Running code-based consensus algorithms, DLT systems enable transaction validation without a single designated authority, thus replacing centralised intermediaries, such as banks, as a source of trust. To the same effect, some DLT systems allow integration of smart contracts, i.e., pieces of code that run on DLT that automate contract execution and other transactional processes. ${ }^{29}$ Smart contracts could automate several administrative intermediary functions in relation, e.g., to corporate actions, tax handling and collateralization. Given that DLT-based databases are also exceptionally difficult to tamper with, it is no surprise that some expect the technology to reform our centralized, exclusionary and antiquated financial market systems, which are based on "a kludge of industrial technologies and paper-based processes dressed up in a digital wrapper." 30

Many have already charted the potential of DLT to overcome the problems and risks inherent in today's intermediated securities holding systems, ${ }^{31}$ the fragmented and opaque securities markets ${ }^{32}$ and even the fragilities of the modern financial system more generally. ${ }^{33}$ From the perspective of the securities holding system debate, the central promise of DLT is that it will reconnect investors with issuers, thus enabling transparent and direct ownership. ${ }^{34}$ Market participants

ors: Problems, Quick Fixes and Long-term Solutions, in: Gullifer/Payne (ibid) and Richard Salter $Q C$, Enforcing Debt Securities, in: Gullifer/Payne (ibid).

29 On blockchains and DLT, See Primavera De Filippi/Aaron Wright, Blockchain and the law: The rule of code, 2018, p. 33-57.

30 Alex Tapscott/Don Tapscott, "How blockchain is changing finance" Harvard Business Review 1.9 (2017), p, 2, 3.

31 Mooney, Beyond Intermediation (fn. 25); Micheler, Custody Chains and Asset Values (fn. 26); Sarah Green/Ferdisha Snagg, Intermediated Securities and Distributed Ledger Technology, in: Gullifer/Payne (fn. 27).

32 David C. Donald/Mahdi H. Miraz, "Multilateral Transparency for Securities Markets through DLT", Fordham Journal of Corporate \& Financial Law 25 (2019), p. 97.

33 Emilos Avgouleas/Aggelos Kiayias, "The promise of blockchain technology for global securities and derivatives markets: the new financial ecosystem and the 'holy grail' of systemic risk containment”, European Business Organization Law Review 20.1 (2019), p. 81.

34 OECD report (fn. 5), p. 16. 
have recognised the efficiency-increasing potential of DLT. ${ }^{35}$ The technology could therefore transform the infrastructure underlying securities transactions, which currently depends on the services of several intermediaries (brokers, clearing members, custodians) and infrastructure providers (trading venues, central counterparties, CSDs). According to the most optimistic predictions, DLT could merge trading, clearing, and settlement into one seamless and uniform global infrastructure. ${ }^{36}$

The emerging token economy is yet to fulfil the visions of borderless peer-topeer networks heralded by the original blockchain protocols. ${ }^{37}$ Re-intermediation rather than disintermediation has been the predominant trend. Participation in DLT systems has been outsourced to wallet providers and other crypto custodians. ${ }^{38}$ Moreover, most crypto-asset exchanges or trading platforms remain centrally operated and controlled and only a few offer direct on-chain integration. ${ }^{39}$

In the EU, several projects have been launched to create DLT-based securities holding systems or post-trade infrastructures. However, regulatory constraints continue to limit the scope and level of ambition of these projects. ${ }^{40}$ The Commission's digital finance package seeks to address some of these constraints.

35 Commission Staff Working Document, Impact Assessment accompanying the document Proposal for a Regulation of the European Parliament and of the Council on a pilot regime for market infrastructures based on distributed ledger technology, 24 September 2020, SWD(2020) 201 final (DLT Impact assessment), p. 21, noting that these benefits in terms of efficiency were expected by almost 4 out of 5 respondents to the public consultation.

36 De Filippi/Wright (fn. 29), p. 94. For a more detailed view of DLT's potential from the perspective of European post-trade infrastructures, see European Central Bank, The potential impact of DLTs on securities post-trading harmonisation and on the wider EU financial market integration. Advisory Group on Market Infrastructures for Securities and Collateral, September 2017 (ECB Report).

37 Randy Priem, "Distributed ledger technology for securities clearing and settlement: benefits, risks, and regulatory implications.” Financial Innovation 6.1 (2020), p. 1, 13. On intermediation and re-intermediation in the digital finance space, see also Iris $\mathrm{H}$-Y Chiu, Fintech and Disruptive Business Models in Financial Products, Intermediation and Markets - Policy Implications for Financial Regulators. Journal of Technology Law \& Policy 21(2016), p. 55.

38 DLT impact assessment (fn. 35), 8; Louise Gullifer/Henry Chong/Hin Liu, Client-Intermediary Relations in the Crypto-Asset World, 23 September 2020 available at http://dx.doi.org/10.2139/ ssrn.3697946 accessed 4 March 2021, p. 1.

39 OECD report (fn. 5), p. 16, p. 30 (also reporting that many exchanges are "contemplating for applying for broker-dealer licence”).

40 MiCA Impact Assessment (fn. 7), p. 21. 


\subsection{The Digital Finance Package and “DLT Market Infrastructures"}

The Digital Finance Package introduces two separate Union regimes for cryptoassets. The MiCA proposal would set up a tailored regime for crypto-assets that currently fall outside the scope of EU financial services legislation, including all crypto-assets that do not qualify as financial instruments, deposits or structured deposits under that same legislation. ${ }^{41}$ The proposal would impose disclosure rules for issuers of crypto assets and numerous requirements for crypto-service providers such as exchanges, custodians, brokers and advisers. ${ }^{42} \mathrm{~A}$ full harmonisation instrument, MiCA would replace all existing national regimes and establish an EU passport for all crypto issuers and service providers. ${ }^{43}$

The MiCA proposal also confirms that all crypto-assets qualifying as MiFID II financial instruments ${ }^{44}$ remain regulated under existing Union financial legislation "regardless of the technology used for their issuance or their transfer". ${ }^{45}$ To the same end, the definition of a 'financial instrument' in MiFID II would be amended "to clarify beyond any legal doubt that [financial] instruments can be issued on a distributed ledger technology." 46 Without alleviating measures, this would set an insurmountable obstacle for security token issuers and service providers. For instance, the CSD Regulation segregates post-trading functions by requiring that all securities traded on trading venues must be issued and recorded in book entry form in a CSD. ${ }^{47}$ Many rules also impose mandatory intermediation, thus preserving the market's multi-tiered and hierarchical structure. For instance, MiFID II requires all members or participants of multilateral trading facilities (MTFs) to be investment firms, credit institutions or other persons meet-

41 MiCA proposal, p. 10.

42 MiCA proposal, recital 12, p. 18.

43 MiCA proposal, p. 7.

44 Defined in Article 4(1)(15) and Annex I C of Directive 2014/65/EU of the European Parliament and of the Council of 15 May 2014 on markets in financial instruments and amending Directive 2002/92/EC and Directive 2011/61/EU, p. 349.

45 MiCA proposal, recital 6, p. 16.

46 Proposal to amend MiFID II and other directives, p. 5.

47 Article 3 of Regulation No 909/2014 of the European Parliament and of the Council on improving securities settlement in the European Union and on central securities depositories and amending Directives 98/26/EC and 2014/65/EU and Regulation (EU) No 236/2012, p. 1-72 (CSD Regulation). 
ing strict competence, resource and organisational arrangements. ${ }^{48} \mathrm{~A}$ similar requirement applies to securities settlement systems (operated by CSDs), which may only admit certain institutional counterparties as participants. ${ }^{49}$ The latter rules would prevent DLT networks or crypto trading platforms from accepting individuals as members. ${ }^{50}$

To overcome these and other structural obstacles, the DLT Pilot Regime would create a specific environment for experimenting with DLT. In effect, the regime would allow certain targeted and temporary exemptions from regulatory rules which refer to notions such as "security account" or "book-entry form". 51 Possible exemptions, detailed under articles 4 and 5 of the DLT Pilot Regime proposal, as well as in the proposed MiFID II amendment, ${ }^{52}$ would be granted on application by national competent authorities and the permission would be valid throughout the Union. ${ }^{53}$ The new licensing regime would therefore operate on a decentralised basis with limited oversight from ESMA. ${ }^{54}$

The decentralised sandbox approach of the DLT Pilot Regime is a necessary first step towards more comprehensive reform. It would be difficult if not impossible to foresee the shape and architecture of evolving technological arrangements for holding and disposing of securities. ${ }^{55}$ Even as a first step, however, the proposed regime is notably conservative. Only CSDs authorised under the CSD Regulation, or investment firms and market operators authorised under MiFID II, would be entitled to apply for permission to operate a new "DLT market infrastructure" - either a "DLT MTF" (in the case of a MiFID II firm) or a "DLT Settlement System" (in the case of a CSD). The proposed regime also only recog-

48 Article 19 of Regulation (EU) No 600/2014 of the European Parliament and of the Council on markets in financial instruments and amending Regulation (EU) No 648/2012, p. 84-148 (MiFID II).

49 Article 2(f) of Directive 98/26/EC of the European Parliament and of the Council of 19 May 1998 on settlement finality in payment and securities settlement systems, p. $45-50$ (the Settlement Finality Directive).

50 For an early review of compatibility issues, see ESMA Advice (fn. 12 above).

51 DLT Pilot Regime proposal, recital 20 (recognising that "double-entry (or multiple-entry) book keeping of securities accounts may not always exist in a DLT system.”).

52 See the proposed amendment to article 19 of MiFID II under the proposal amending MiFID II and other directives. As the proposal explains (recital 8) "DLT multilateral trading facility should be allowed to request a derogation from such an obligation so that is can provide retail investors with easy access to the trading venue, provided that adequate safeguards are in place in terms of investor protection."

53 DLT Pilot Regime proposal, p. 8. For DLT MTFs, see Article 7(5) of the DLT Pilot Regime proposal.

54 See articles 7(3) and 8(3) of the DLT Pilot regime proposal.

55 See recital 4 of the DLT Pilot Regime proposal. 
nises restricted or permissioned DLT networks. Unlike the MiCA proposal, the DLT Pilot Regime proposal does not allow building tokenisation solutions on open and permissionless DLTs such as Ethereum - so far the dominant platform for STOs. ${ }^{56}$ The proposal clarifies that the new DLT market infrastructures "should establish the rules on the functioning of the proprietary DLT they operate, including the rules to access and admission on the DLT[...]." 57 DTL infrastructures would therefore be designed, owned, operated and governed by licensed firms. As a moderate sign of a more disruptive approach, a DLT MTF could be licensed to perform certain important functions now reserved for CSDs, such as taking care of the initial recording of securities (the notary function) and settlement of transactions. ${ }^{58}$

The Pilot Regime would also have a limited material scope. The proposed regime would apply to transferable securities that are negotiable on the capital market and exclude, e.g., private placements of unlisted SMEs. ${ }^{59}$ To safeguard financial stability, the regime would also be limited to illiquid securities that do not exceed a specified market value: the maximum market capitalisation for issuers of shares would be EUR 200 million. For public bonds other than sovereign bonds (which would be excluded) the maximum issue size would be EUR 500 million. To control the size of the new infrastructures, the proposal limits the

56 See French Digital Asset Association (FD2 A) et al., Report on "security tokens" or "financial tokens similar to financial instruments.”, p. 1, available at https://www.afg.asso.fr/wp-content/ uploads/2019/05/report-on-security-tokens-may-2019-1.pdf accessed 4 March 2021 (finding that a vast majority of players involved with issuing or servicing security tokens opt for a public blockchain). For one example, see, e.g., OECD report (fn. 5), p. 47 describing how Swiss company Mt Pelerin Group SA tokenised all of its issued (and uncertificated) shares on the Ethereum blockchain (a combination of public offering and private placement). Société Générale, a French bank, has completed two covered bond issues using the Ethereum blockchain. See FitchRatings, SG Covered Bonds Issued and Settled with Blockchain Technology, 21 May 2020, available at https://www.fitchratings.com/research/banks/sg-covered-bonds-issued-settled-with-blockchaintechnology-21-05-2020 accessed 4 March 2021.

57 DLT Pilot Regime proposal, recital 28. Compare recital 5 of the MiCA proposal which notes that "a Union framework on markets in crypto-assets should not regulate the underlying technology and should allow for the use of both permissionless and permission-based distributed ledgers.".

58 DLT Pilot Regime proposal, recital 9.

59 As defined under MiFID II Article 4(1)(44), i.e., securities such as shares or bonds or other forms of securitised debt (incl. depository receipts in respect of shares or debt securities). See DLT Pilot Regime proposal, recital 11 ("DLT transferable securities should be crypto-assets that qualify as 'transferable securities' within the meaning of [MiFID II] and that are issued, transferred and stored on a distributed ledger.”). 
total market value of securities recorded on either of the new DLT market infrastructures to EUR 2.5 billion.

To conclude, the Digital Finance Package facilitates disintermediation by enabling disapplication of certain mandatory EU financial services rules that, e.g., centralise the recording of securities within CSDs and disqualify all but certain professional financial firms from participating in trading platforms and securities settlement systems. At the same time, users would access security token markets through established and licensed gateway service providers, which would also remain the central points of responsibility for regulatory and supervisory purposes. The proposal's main purpose therefore seems to be eradication of regulatory barriers to investment in digital infrastructure by existing market players, which are struggling to match increasing competition from their peers outside the EU. ${ }^{60}$

\section{The Case and Opportunity for Private Law Harmonisation}

\subsection{Legal Uncertainty on Substantive Rights and Applicable Law}

Levelling the regulatory playing field for DLT market infrastructures does not alone make the arrangements legally sound. ${ }^{61}$ Even a perfectly transparent "single golden record" 62 of transactions and security ownership would fail to provide legal certainty in a cross-border context unless all the jurisdictions involved treated the recorded rights and interests (replicated in identical form throughout the cross-border network) in a legally compatible way. Such private law issues are ignored in the Commission's Digital Finance Package, which includes no initiatives as to rights of token holders vis-à-vis the operators of DLT market infrastructures, their participants, or creditors of both. The case for such harmonisa-

60 A good example of the type of DLT infrastructure envisaged by the DLT Pilot Regime is the SDX project by SIX, a company that owns and manages Switzerland's stock exchange. SDX would host a fully integrated infrastructure for trading, settlement and custody of digital assets. See SIX, https://sdx.com/ accessed 4 March 2021.

61 BIS Committee on Payments and Market Infrastructures (CPMI), Distributed ledger technology in payment, clearing and settlement. An analytical framework, February 2017, 16 ("DLT can increase legal risks if there is ambiguity or lack of certainty about an arrangement's legal basis.") 62 See MiCA Impact Assessment (fn. 7), p. 22. 
tion is clear. For instance, the revised CMU strategy acknowledges that a key to encouraging cross-border investment is ensuring that investors may rely on adequate and effective legal protection in other Member States. ${ }^{63}$ This applies to the DLT market infrastructures and their legal underpinnings as well.

However, there is nothing new in such legal uncertainty with regard to end investors' ownership rights. On the contrary, it has been a permanent feature of European markets for intermediated securities. As the 2017 European Post-Trade Forum Report explains:

Across the EU, Member States have developed legal mechanisms which are intended to ensure that an end investor enjoys in rem "ownership" of securities, notwithstanding that a chain of intermediaries may separate the end investor from the issuer. These mechanisms work reasonably well within each Member State. But the mechanisms differ from each other, and can come into conflict if the chain of intermediaries crosses borders. ${ }^{64}$

In the case of intermediated securities, it has therefore been assumed that the legal position of account holders is relatively secure as long as the chain of custodians does not involve intermediaries from other jurisdictions (with possibly conflicting laws). A similar assumption could not be made in the case of security tokens. EU jurisdictions are already split on how they apply their securities laws to security tokens: some Member States have enacted (or are in the process of enacting) laws that characterise security tokens as securities while in other Member States the issue would be resolved via unpredictable rules governing intangible property. ${ }^{65}$ Many national legal systems are yet to adapt to the requirements of DLTs, security tokens and other crypto assets. ${ }^{66}$ Lack of common or compatible rules would further fragment the private law underpinnings of EU capital markets and expose future token holders to a patchwork of unpredictable and inconsistent Member State laws.

63 Communication from the Commission, A Capital Markets Union for people and businesses new action plan COM/2020/590 final, p. 14.

64 EPTF Report (fn. 20), p. 85.

65 See Clifford Chance report (fn. 9 above); Kulms in this volume; Matthias Lehmann, "National Blockchain Laws as a Threat to Capital Markets Integration.” Uniform Law Review 26 (2021), p. 148.

66 As a good example of such modernisation, in December Germany initiated a law project the purpose of which is to allow recording of securities in crypto securities registers. See the proposal and press release of the Federal Ministry of Justice, Gesetz zur Einführung von elektronischen Wertpapieren, available at https://www.bmjv.de/SharedDocs/Gesetzgebungsverfahren/DE/Einfuehrung_elektr_Wertpapiere.html accessed 4 March 2021. Compare the reforms of France and Luxembourg as, e.g., described in the report by the French Digital Asset Association (FD2 A) et al. (fn. 58), p. $2-3$. 
This legal uncertainty is amplified by unclear rules of private international law. It is unclear how the EU's existing conflict-of-laws rules applicable to intermediated securities would apply - if they were to apply at all - to security tokens held within DLT market infrastructures. Without uniform conflict rules, any harmonisation of substantive law (short of absolute unification of relevant property, insolvency and corporate law) would fail to resolve the legal risks attaching to security tokens. Leaving the issue to be resolved by each Member State would lead to inconsistent and incompatible outcomes, particularly considering the large menu of alternative conflict rules available. ${ }^{67}$ Therefore, just as in the case of intermediated securities, harmonisation of conflict-of-law rules should be considered a priority. ${ }^{68}$

\subsection{The Opportunity for Private Law Harmonisation}

For good reason, securities law is considered one of the most challenging areas of private law to harmonise. ${ }^{69}$ In addition to the topic's general complexity and technicality, negotiators must cope with a diversity of national legal approaches and technical arrangements. ${ }^{70}$ The onset of security tokens and DLT market infrastructures will complicate the mix of laws and technologies even further. One might reasonably expect that this will also diminish the chances of success of (currently stagnant) harmonisation projects. This section argues the contrary:

67 For review and discussion, see the FMLC report (fn. 5).

68 Matthias Haentjens, European Harmonisation of Intermediated Securities Law: Dispossession and Segregation in Regulatory and Private Law, in: Gullifer/Payne (fn. 28 above), 259287, p. 261; FMLC report (fn. 5), p. 5-6. See also Recommendation 8 of the Expert Group on Regulatory Obstacles to Financial Innovation (fn. 11).

69 Luc Thévenoz, The Geneva Securities Convention: objectives, history, and guiding principles, in Conac/Segna/Thévenoz, Intermediated Securities: The Impact of the Geneva Securities Convention and the Future European Legislation. (New York: Cambridge University Press, 2013), p. $16-17$.

70 Thévenoz, ibid., p. 16-17. For instance, in 2005 Goode et al. listed the following established legal constructs to characterise the account holder's legal position: "Regular deposit; special deposit; co-property rights in an identifiable pool of securities; some other form of property right traceable to individual securities; irregular deposit; general deposit; some other form of purely personal (contractual) right against the intermediary to the delivery or transfer of a given type and number of securities; interest of a beneficiary under a trust; a statutory fiduciary interest; Gutschrift in Wertpapierrrechnung; co-property rights in a fungible, notional or book-entry pool of securities; security entitlements; some other bundle of property, contractual or other rights." Roy Goode/Hideki Kanda/Karl Kreutzer (with the assistance of Cristophe Bernasconi), Hague Securities Convention, Explanatory Report, 2005. 
that digitisation of finance has created a window of opportunity for private law harmonisation that should not be missed.

First, the versatile legal problems of digital financial assets are new to all jurisdictions, which means that divisive doctrinal tradition would less likely defeat harmonisation attempts. Compare this situation to the happenstance mix of laws and systems of intermediated securities that has evolved over decades as each country has aligned its laws with its own needs, traditions, markets and infrastructures. ${ }^{71}$ Some countries have adapted the law to market practice while others have done the exact opposite; still others have done either nothing at all or have adopted hybrid approaches, flexing existing legal concepts and institutions to confusing limits. ${ }^{72}$ These legal-cultural differences have complicated the EU securities law legislation project, which has failed to produce a legislative proposal. ${ }^{73}$ The onset of digital financial assets is forcing legislators, courts, and legal scholars to ask similar questions: whether to adapt the law to the market, or vice versa; whether existing doctrines of property are fit to deal with digitized assets and DLT infrastructures, and so on. In response, several countries have already enacted private law reforms. However, the outcomes are hardly as entrenched as in the case of intermediated securities, nor are they as wrapped up in anachronistic doctrines of property. By adopting a proactive minimum harmonisation approach early on and as a first-step measure, the EU would ensure a minimum level of protection for token holders while mitigating the risk of replicating the fragmented legal system for intermediated securities. ${ }^{74}$

Second, the DLT Pilot Regime would be an ideal opportunity for private law harmonisation because of its limited scope. In addition to legal and cultural obstacles, legal reform of the intermediated system has been subdued by conflicting market demands. The modern financial system hosts two classes of investors whose interests and priorities do not align. The first class represents investors who hold securities as medium-term or long-term investments and who value effective governance and enforcement rights in addition to protection against third-party claims; the second class of investors operates mainly on the short-

71 Thévenoz (fn. 69), p. 18. As the Giovannini report of 2001 noted, "laws about what securities are and how they may be owned form a basic and intimate part of the legal systems of Member States, and to change them will have many ramifications." Giovannini report 2001 (fn. 18), p. 54. 72 Philipp Paech, Conflict of Laws and Relational Rights, in: Gullifer/Payne (fn. 28 above), p. $290-291$.

73 See e. g. Madeleine Yates/Gerald Montagu, The law of global custody: legal risk management in securities investment and collateral, $4^{\text {th }}$ ed., 2013, p. 201-202.

74 See also Paech, Securities, intermediation and the blockchain (fn. 21), p. 614; Lehmann (fn. 65). 
term securities financing market and prioritises liquidity, cheap credit and effective collateralisation. ${ }^{75}$ According to Benjamin and Gullifer, the commercial pressures of the growing securities financing market are partially responsible for the ongoing structural separation of investors from their entitlements. ${ }^{76}$ Lack of consensus has also obstructed legal reform. ${ }^{77}$ DLT-based holding systems are not immune to these conflicting market demands, at least in the long term. However, the interests and priorities of the securities financing market need not affect the design of the first generation of European DLT infrastructures, which - as the proposed DLT Pilot Regime suggests - could only be used for illiquid securities of limited value. Such systems could therefore be designed to respond to the needs of medium-term and long-term investors without the corresponding tradeoffs for, or opposition from, the securities financing market.

\subsection{Disintermediated Systems and Securities Law Harmonisation}

A possible hindrance for the creation of "EU security tokens law" is that the legal systems of most Member States are relatively unfamiliar with transparent securities holding systems or their specific legal needs. Various categories of transparent holding systems exist but they all recognise the ultimate account holder's interest at the CSD level. ${ }^{78}$ Such "end-investor segregation" is possible and popular in some Member States such as the Nordic countries, ${ }^{79}$ but most Member States subscribe to the intermediated model. ${ }^{80}$

75 See Benjamin/Gullifer (fn. 27); Gullifer/Payne, Conclusions, in: Gullifer/Payne (fn. 27), p. 391, p. 393 and 396. Such divisions are visible even within single financial institutions. See Paech, Market Needs as Paradigm: Breaking Up the Thinking on EU Securities Law, in Conac/Segna/ Thévenoz (fn. 69), p. 25.

76 Benjamin/Gullifer (fn. 27), p. 215.

77 Ibid., p. 231, p. 234.

78 Unidroit, Report of the Transparent Systems Working Group, Study LXXVIII - Doc. 88, May 2007, 2. See also ECSDA, Account segregation practices at European CSDs, 13 October 2015, available at http://ecsda.eu/wp-content/uploads/2015_10_13_ECSDA_Segregation_Report.pdf accessed 4 March 2021, p. 2-3. Such systems have also been called transparent. However, see Mooney, Beyond intermediation (fn. 25), p. 398-399 (noting that the term is misleading since "this does not necessarily mean that the investor's identity is disclosed to any particular person, much less made available to the public generally").

79 See Lars Afrell/Karin Wallin-Norman, "Direct or Indirect Holdings-A Nordic Perspective." Uniform Law Review 10 (2005), p. 277, 283. For the features of the "end-investor segregation model" as opposed to "individual client segregation" (where the client can also be an intermediary act- 
In international harmonisation projects, transparent holding systems have mainly represented distracting deviations from mainstream intermediated holding models, which have provided the blueprint for harmonisation. The Geneva Securities Convention, completed in 2009, struggled to accommodate the specific features of transparent holding systems. Compatibility problems related, for example, to the special operational and administrative role of CSD participants in controlling CSD accounts directly, technical integration of intermediaries' systems with those of the CSD, and the general problem of whether and when CSD participants could qualify as "intermediaries". ${ }^{81}$ Permissioned DLT systems, directly accessible by individuals (including foreign), will probably introduce similar issues. The participants or nodes of DLT systems, acting as points of entry to the DLT infrastructure, might not qualify as intermediaries, at least in the traditional sense - unless they acted as custodians and used their own separate systems for the purposes of recording their clients' security tokens.

The marginal status of transparent holding systems has been mainly due to their negligible international importance. It has been assumed that transparent systems simply do not work for cross-border holding of securities. ${ }^{82}$ Indeed, most transparent systems (including those hosted by the Nordic countries) are mixed systems where a significant proportion of the holding chain is non-transparent (intermediated) in order to facilitate international access and cross-border securities trade. ${ }^{83}$

DLT-powered disintermediation means that transparent holding systems might be much less marginal in the future. After all, the entire point of DLT is to enable disintermediation in a cross-border environment. The explicit objective of the DLT Pilot Regime is to promote direct access for retail investors to new DLT infrastructures, ${ }^{84}$ which could operate freely in the single market with a Unionwide passport. In building the legal foundations for such systems, much could

\footnotetext{
ing on end-investors behalf) and "omnibus client segregation" (where client securities are pooled or commingled at the CSD level) models, see ECSDA 2015 (ibid) p. 8 and Delphine Nougayrède, "Towards a Global Financial Register? The Case for End Investor Transparency in Central Securities Depositories”, Journal of Financial Regulation 4.2 (2018), p. 276, p. 286-288. 80 See ECSDA 2015 (fn. 78) p. 11.

81 Unidroit report (fn. 78).

82 Victoria Dixon, The Legal Nature of Intermediated Securities: An Insurmountable Obstacle to Legal Certainty?, in: Gullifer/Payne (fn. 27), p. 47-83, p. 62.

83 Unidroit Report (fn. 78) (noting that "Individual client or end investor account segregation typically does not apply in cross-border scenarios").

84 As recital 22 of the proposed regulation clarifies, one purpose of the pilot regime is to eradicate regulatory obstacles "to the development of alternative models of settlement based on a DLT that allow direct access by retail clients.".
} 
be learned from legal systems hosting transparent and mixed holding systems. For instance, since the 1990s the Nordic countries have had in place special legislation clearly defining the ownership rights of end-investors at their national CSDs. ${ }^{85}$ However, these systems are equally unprepared for the demands and intricate technical details of DLT-based systems. Definitional confusion about accounts, records, ledgers and their possible legal differences will hardly be avoided. ${ }^{86}$

\section{Elements of EU Security Tokens Law}

\subsection{Which Conflict of Laws Rule for Security Tokens and Direct Holding Systems?}

The absence of consistent rules for establishing the applicable law for issues of ownership rights and other proprietary interests in intermediated securities remains an important legal barrier for the development of the EU single financial market. ${ }^{87}$ In the case of intermediated book entry securities, the problem is not the lack of EU-level rules so much as their diversity and limited scope. The existing rules, representing variations of the so-called Place of the Relevant Intermediary Approach (PRIMA), ${ }^{88}$ refer as a connecting factor to (a) the country where the relevant register, account or centralised deposit system recording the security is located (Settlement Finality Directive (SFD); ${ }^{89}$ (b) the country where the register, account or system is held or located (the Winding-up Directive (WUD) $)^{90}$; and

85 Afrell/Wallin-Norman (fn. 79), p. 277. Most Nordic CSDs also act as formal registrars under corporate law and operate national settlement systems. See ECSDA 2015 (fn. 68) p. 8 and Nougayréde (fn. 79) p. 285.

86 Priem (fn. 37), p. 18.

87 The EPTF Report (fn. 20), p. 71. The barrier was originally identified in the Giovannini Reports of 2001 and 2003. See the Giovannini 2001 report (fn. 18 above) and The Giovannini Group, Second Report on EU Clearing and Settlement Arrangements, April 2003. See also Legal Certainty Group, Second Advice of the Legal Certainty Group: Solutions to Legal Barriers Related to Post-trading within the EU, August 2008; and European Commission, Securities Law Legislation: 7th Meeting of the Member States Working Group: Non-paper, 15 May 2013.

88 The PRIMA approach was developed during negotiations for The Hague Convention of 5 July 2006 on the Law Applicable to Certain Rights in Respect of Securities (effective as of 1 April 2017).

89 Article 9(2) of the Directive 98/26/EC of the European Parliament and of the Council of 19 May 1998 on settlement finality in payment and securities settlement systems, p. 45.

90 Article 24 of the Directive 2001/24/EC of the European Parliament and of the Council of 4 April 2001 on the reorganisation and winding up of credit institutions, p. 15. 
(c) the country where the relevant account is maintained (the Financial Collateral Directive (FCD) $)^{91}$. The Commission recently assessed the compatibility of these approaches and the diversity of their national interpretations, if only to conclude that they all "appear to be valid" and that there was no need for legislative action. ${ }^{92}$

It would be difficult to predict how the existing conflict rules designed for intermediated securities and account-based structures would be applied in a DLT context - if they were to apply at all considering their limited substantive and personal scope. On the one hand, in a pure DLT environment the PRIMA rule based on the location of the account or register, or the location of the entity in charge of maintaining the account or register, would not work for the simple reason that there are neither accounts nor intermediaries in the traditional sense. ${ }^{93}$ Indeed, the main feature of distributed registers - shared and replicated across a transnational network of nodes - is that tokens exist at the same time everywhere and nowhere in particular. ${ }^{94}$ On the other hand, in the case of permissioned or proprietary DLT holding systems it would not be clear whether the notion, e.g., of "maintaining" a register or system would be interpreted as referring to the licensed entity responsible for the entire system (the provider of the "DLT market infrastructure") or the entity (e.g., node, member, participant) that makes the entries in the system based on a mandate or agreement. ${ }^{95}$

To design the most appropriate conflict-of-laws rules for DLT systems requires a balancing of multiple policy and legal issues as well as market needs. For disintermediated holding systems, the most logical conflict-of-laws rule would be the law governing the DLT system. In fact, such a rule has already

91 Art. 9(1) of the Directive 2002/47/EC of the European Parliament and of the Council of 6 June 2002 on financial collateral arrangements, p. 43, as amended by Directive 2009/44/EC of the European Parliament and of the Council of 6 May 2009 amending, p. 37.

92 Communication from the Commission to the European Parliament, the Council, the European Economic and Social Committee and Committee of the Regions on the applicable law to the proprietary effects of transactions in securities, 12 March 2018COM(2018) 89 final, p. 5-6.

93 Green/Snagg (fn. 31), p. 354; Thomas Keijser/Charles W. Mooney Jr, Intermediated Securities Holding Systems Revisited: A View Through the Prism of Transparency, in: Gullifer/Payne (fn. 27), p. 325. See also the FMLC report (fn, 5), p. 6 and Kulms in this volume (discussing the case Ruscoe v. Cryptopia Ltd., [2020] NZHC 728).

94 ESMA Advice (fn. 12), para. 72 (In a DLT environment, it might be less clear where the securities and their records are located); FMLC report (fn. 5), p. 11.

95 These problems are not alien to intermediated securities either because to speak of a "location" of a securities account is also a simplification. See the EPTF report (fn. 20), p. 76. See also Unidroit report (fn. 78), p. 11-13 discussing the problem of defining the "relevant intermediary" in so-called transparent systems. 
been identified and discussed; a rule termed "PROPA" would look to the "Place of the Relevant OPerating Authority/Administrator" of the DLT system. ${ }^{96}$ This type of rule would fit well with the approach adopted in the proposed DLT pilot regime because it only works if the relevant holding system is permissioned and centrally operated and administered. ${ }^{97}$ In the DLT Pilot Regime context, the governing law would therefore be linked to the location of the licensed DLT Market Infrastructure provider.98

The PROPA rule, however, involves important trade-offs. The "law of the system" approach would mean that an investor holding security tokens issued through different DLT systems (applying different laws) would have to ascertain the certainty of their legal title to, and other interests in, security tokens in each jurisdiction. ${ }^{99}$ An investor wishing to buy security tokens on margin, for instance, would find it cumbersome to use the portfolio, and its changing content, as collateral. Indeed, the oft-cited benefit of the above-discussed PRIMA rule and the "no-look-through" principle is that they facilitate diversification and efficient portfolio financing. They allow a single law to apply to a securities account, and to all the securities credited on that account, regardless of their origin. ${ }^{100}$

The same drawback concerns another possible conflict-of-laws approach which has been called elective situs. According to this rule, the proprietary effects of transactions would be governed by the law "chosen by the network participants for the DLT system." 101 All tokens and transactions within the system would be governed by a single legal framework and all system participants would agree to the applicable law by way of a contract when connecting to the DLT system. ${ }^{102}$ Like the PROPA rule, elective situs might not facilitate collateralisation and market integration. Moreover, political consensus for such a party autonomy-based approach would be difficult to achieve. The Hague Securities Convention was rejected by many EU Member States precisely because the contractual PRIMA rule ultimately adopted would have allowed displacing national property and insolvency laws with a foreign law (e.g. English or New

96 FMLC report (fn. 5).

97 FMLC report (fn. 5), p. 18.

98 FMLC report (fn. 5), p. 18. Such "lex systematis" is also discussed - and tentatively supported - in Paech, Securities, intermediation and the blockchain (fn. 21), p. 636.

99 Yates/Montagu (fn. 84), p. 101 and Paech (fn. 72)

100 Paech (fn. 72), p. 294; Keijser/Mooney (fn. 93), p. 324. According to Gullifer and Payne, this is "probably the most significant advantage of the intermediated system, and the one most difficult to replicate in other ways”. See Gullifer/Payne, (fn. 75) p. 362.

101 FMLC report (fn. 5), p. 15.

102 Again, this would be a workable option especially for proprietary permissioned systems. FMLC report (fn. 5), p. 16. 
York law) as long as the relevant intermediary had a branch in that foreign jurisdiction when entering into the contract. ${ }^{103}$ The party autonomy approach has nevertheless received support in the crypto asset context. ${ }^{104}$

The drawbacks of the PROPA or the elective situs rules in terms of cross-border investments or portfolio financing would naturally depend on the number of relevant infrastructure providers and the number of laws applying to them. The higher the number of infrastructures and therefore of applicable national laws, the higher the attendant transaction costs. The transaction cost problem could therefore be mitigated by market consolidation driven by economies of scale. But this might also support an oligopoly of centrally controlled holding systems, which would hardly be the best way to support efficient and competitive digital capital markets, especially in terms of trading cost and the cost of using and accessing the new cross-border financial market utilities. ${ }^{105}$ Of course, legal diversity within Europe could also be mitigated via a radical substantive harmonisation agenda.

A third conflict-of-laws solution would be to preserve the PRIMA approach as an alternative. As the market for security tokens evolves, investors are likely to access security tokens held in a variety of DLT infrastructures through "global crypto custodians" or other gateway services. ${ }^{106}$ These arrangements could be facilitated by a modified PRIMA rule (contractual or factual) which would look at the place of the relevant participant in the DLT system. Such a conflict rule (which could be called PREPA) would support both market integration as well as competition and efficiency by allowing, just as the PRIMA rule, the investor to hold a portfolio of securities "in one account [or address] with one intermediary in one jurisdiction." ${ }^{107}$ A rule of this kind would contribute to the shortening of custody chains as it would only cover direct participants of the holding systems. ${ }^{108}$ Alongside this conflict rule, the above-discussed PROPA rule (or elective

103 Paech, Conflict of Laws and Relational Rights (fn. 83) p. 293; FMLC report (fn. 5), p. 15-16. 104 FMLC report (fn. 5); Haentjens/de Graaf/Kokorin (fn. 17), 27 (arguing "that the Hague Securities Convention approach is the most appropriate approach for proprietary claims of customers against their crypto-custodians.”).

105 Indeed, crypto-economy is not alien to oligopolistic pressures. See Avgouleas/Seretakis in this issue. A recent article by Priem explains how investor segregation at CSD level affects settlement costs and inter-CSD competition. Randy Priem Asset Segregation at CSDs: Protecting Investors with a Level Playing Field. European Business Law Review 31.5 (2020).

106 Beyond security tokens, some wallet producers (custodians) already support multiple crypto-assets and DLT systems. See Pilot regime IA, p. 8.

107 Gullifer/Payne (fn. 75), p. 366.

108 Nowadays direct participation in national CSDs requires costly legal, technical and operational arrangements, which is why many intermediaries choose to access foreign CSDs indirectly, 
situs) could apply to direct relationships between a participant (token holder or an intermediary acting on its behalf) and the DLT market infrastructure. This discussion is tangential to the bigger issue of market structure and intermediation, which will be briefly discussed in the next section.

\subsection{Intermediated Access to DLT Market Infrastructures}

The DLT Pilot Regime proposal is (perhaps deliberately) silent on intermediated access to the envisaged DLT market infrastructures. However, the proposal does indicate that the business plan of a DLT market infrastructure may involve safekeeping of clients' funds, such as security tokens, or the means of access to them "including in the form of cryptographic keys". ${ }^{109}$ Operators of a piloted DLT system could therefore act as custodians and administer the client's tokens on their behalf and even under their own name. Nothing in the Digital Finance Package indicates that participants or members of DLT market infrastructures could not perform such intermediary functions. The DLT Pilot is equally silent on use of omnibus accounts (or addresses) for pooling investor's tokens. ${ }^{110}$ However, participants in DLT Settlement Systems could be exempted from the present obligation to offer their clients both omnibus client segregation and individual client segregation. ${ }^{111}$ In other words, national authorities could grant a licence to a national CSD to operate a DLT Settlement System that does not offer omnibus segregation.

Such flexibility should be welcomed. DLT infrastructures need not ban intermediation or disqualify nominee or omnibus structures to mitigate the legal risks of intermediated securities or to increase the efficiency, reliability and transparency of their record-keeping. ${ }^{112}$ Reconciliation, i.e., matching of internal records across the custody holding chain, is currently particularly time-consuming and

usually via global custodians or international CSDs. Christopher Twemlow, Why are Securities Held in Intermediated Form?, in: Gullifer/Payne (fn. 27), p. 94-95. See also Mooney, Beyond intermediation (fn. 25): "involving only one intermediary [a global custodian] would avoid the exacerbated custody-chain risk of holding through a chain of intermediaries across borders.”

109 DLT Pilot regime proposal, p. 16-17. In public-private key cryptography the private key functions as an instrument of authentication and encryption, while the public key and the shorter public address are publicly known and used for identification.

110 It is not uncommon that crypto custodians pool their clients' cryptocurrencies on omnibus addresses. As Haentjens/de Graaf/Kokorin (fn. 17) show, this increases legal risks.

111 This obligation is currently laid down by article 38 of the CSD Regulation, which is among the exemptible rules listed under art. 5(2) of the DLT Pilot Regime proposal.

112 Keijser/Mooney (fn. 93), p. 321. 
labour-intensive. ${ }^{113}$ Successfully standardised and implemented, DLT could eliminate data discrepancies and facilitate quicker or near instantaneous reconciliation of information, shared throughout the network of market participants in a common format. ${ }^{114}$ The possible use of omnibus addresses would nevertheless mean that part of the records might be kept in the intermediaries' own disparate systems. This underlines the continuing relevance of intermediated securities law.

Flexibility would also be needed if the DLT market infrastructures (and the legal frameworks underpinning them) were in the future to provide a credible alternative to present intermediated systems. ${ }^{115}$ As already discussed, modern securities markets host a diversity of market participants with diverse needs (see section 3.3. above). In a similar vein, Mooney has observed that one of the main challenges of any future direct holding model is the need "to preserve the flexibility of existing intermediated systems that accommodate transactional patterns of financing, collateralization, and securities lending."116 The proposal by Benjamin and Gullifer of a bifurcated system where intermediated securities would be replaced by depositary receipts deserves closer scrutiny, also in the context of tokenisation of securities. ${ }^{117}$ Interestingly, at least one non-custodial liquidity solution for token lending is already functioning and quickly expanding in decentralised finance (DeFI) space. ${ }^{118}$

The real challenge lies in combining a regime based on investor choice with rules and incentives that help make direct holding ("end-investor segregation") an affordable and attractive alternative. Some countries such as Sweden have succeeded in this, while in other countries, such as the UK, direct holding has become prohibitively costly and unpopular despite being legally possible. ${ }^{119}$

113 As an ECB study explains: "Each entity involved in the processing of financial transactions currently keeps an independent central record of its clients' asset holdings and needs to reconcile this record with data kept in other centrally managed databases at different levels of the post trading value chain.” ECB report (fn. 36 above), 8. See also CPMI 2017 (fn. 63), 13.

114 CPMI 2017 (fn. 61), 13.

115 The case for complete tokenisation of public equities in developed markets is far from straightforward. See OECD report (fn. 5), p. 29.

116 Mooney, Beyond intermediation (fn. 25), 401.

117 Benjamin/Gullifer, Stewardship and Collateral (fn. 28).

118 See the Aave open source DeFi protocol available at https://aave.com/, accessed 4 March 2021. Within the protocol, interest bearing tokens are minted upon deposit and burned when redeemed.

119 See Gullifer/Payne (fn. 28) 


\subsection{A Modest Proposal for Substantive Harmonisation}

The DLT Pilot Regime Proposal seeks to ensure that clients of new DLT market infrastructures could retrieve their funds in the event of default, resolution or insolvency of the infrastructure provider. To achieve that goal, the proposal effectively replicates the EU's existing client asset regime. ${ }^{120}$ Infrastructure providers are prevented from using client assets on their own account and without clients' express consent. ${ }^{121}$ The operator (whether an investment firm or market operator or a CSD) should also maintain safe, accurate, reliable and retrievable records of client assets and segregate the assets from its own assets as well as from its other clients' assets. In addition, operators should ensure that assets are protected from hacking, theft and other unauthorised access. ${ }^{122}$ The DLT pilot regime would also require that DLT market infrastructures preserve the integrity of security token issues and ensure effective asset segregation regardless of, and as a precondition for, any exemption from applicable law granted by national authorities (see section 2.2 above). ${ }^{123}$

Consistent with the existing regime, the proposed rules on client assets are purely operational and as such do not guarantee the effectiveness of investors' rights. Whether the investor qualifies as the "owner" of the asset in question depends on national provisions on property, insolvency and company law, none of which have been harmonised at EU level. ${ }^{124}$ Introducing yet another regulatory framework for client asset segregation, the proposed regulation also adds to the general inconsistency and diversity of this area of EU financial services law. ${ }^{125}$

The operational approach is partly justifiable given the maturity of the market structure and the incomplete understanding of its drivers. Even if the necessary political consensus existed, EU-wide harmonisation, let alone comprehensive unification of substantive laws regarding security tokens, would be

120 The EU's existing financial services law ensures the availability and identifiability of client assets in such stress situations mainly through MiFID II (articles 16(8) and 16(9) and various sectoral legislations, which all require operational segregation of client securities and prohibit their use without clients' express consent. For a succinct review and discussion of existing EU legislation, see Haentjens (fn. 68), p. 272-277. See also EPTF report (fn. 20), p. 46-49.

121 Article 6(5) of the DLT Pilot Regime proposal (safekeeping including the safekeeping of "the means of access" to such assets, "including in the form of cryptographic keys").

122 Article 6(5)(2)-(4).

123 See Articles 4 (for DLT MTF) and 5 (for DLT Settlement Systems) of the DLT Pilot Regime proposal.

124 Haentjens (fn. 68 above).

125 EPTF report (fn. 20), p. 49. 
premature. Such fundamental issues as the exact moment when legal title to security token passes or the moment when a transaction becomes final and irrevocable would be difficult to define at the current experimental stage. ${ }^{126}$ Imperfect knowledge, however, does not preclude less interventionist measures exemplified by the functional approach of previous international and European securities law projects. The approach entailed drafting rules using language as neutral as possible and by reference to facts and results instead of legal notions and concepts. ${ }^{127}$ The functional approach has so far served as an instrument to steer clear from conceptual and cultural disagreement, but it could also work as a more future-oriented harmonisation tool. For instance, using Article 22(8) of UCITS V ${ }^{128}$ as a model, the DLT Pilot Regime could include the following simple rule:

Member States shall ensure that in the event of insolvency of the operator of a DLT market infrastructure, the funds, collateral and DLT transferable securities of the members, participants, issuers or clients using the DLT market infrastructure are unavailable for distribution among, or realisation for the benefit of, creditors of the DLT market infrastructure.

Such a result-oriented rule would not address all insolvency-related risks (e.g., of possible intermediaries) let alone harmonise proprietary issues relating to legal transfer, priority, and security perfection. On the contrary, it would only address the most fundamental custody risk especially as regards novel holding systems operated by MiFID investment firms or market operators. In the functionalist spirit, however, it would accommodate a variety of national approaches and infrastructures with varying technical detail, leaving room for learning and incremental harmonisation in the future. The proposed rule would also be compat-

126 Bank for International Settlements, Distributed ledger technology in payment, clearing and settlement: An analytical framework, 2017, available at https://www.bis.org/cpmi/publ/d157.pdf accessed 4 March 2021 (noting that "fixing the point in time when the settlement can be considered as final will be very burdensome in a DLT environment as it might not be a clear moment in time”. See also CPMI 2017 (fn. 61), p. 16. It should be noted that the DLT Pilot Regime would not require that the new DLT market infrastructures are notified as securities settlement systems under the Settlement Finality Directive.

127 The UNIDROIT Study Group on Harmonised Substantive Rules Regarding Indirectly Held Securities, Position Paper, UNIDROIT 2003 - Study LXXVIIII - Doc. 8, August 2003, p. 5-6, available at www.unidroit.org accessed 4 March 2021.

128 Directive 2014/91/EU of the European Parliament and of the Council of 23 July 2014 amending Directive 2009/65/EC on the coordination of laws, regulations and administrative provisions relating to undertakings for collective investment in transferable securities (UCITS) as regards depositary functions, remuneration policies and sanctions, p. 186-213. 
ible with the client asset rules as currently included in the DLT Pilot Regime proposal.

The minimum harmonisation approach might also prompt beneficial forms of regulatory competition as transactions and holding systems gravitated to Member States with the most solid, flexible and predictable laws. Indeed, compatibility of legal systems does not necessarily require total substantive harmonisation; gentler approaches are available and diversity may even be instrumental for advancing objectives such as market integration. ${ }^{129}$

\section{Conclusions}

The Digital Finance Package will provide much needed legal certainty for markets in crypto assets. The innovative EU sandbox approach for DLT market infrastructures and security tokens also enables a degree of experimentalism, even within its somewhat confined and conservative scope. However, by disqualifying the use of permissionless DLT networks for issuing and holding security tokens, the EU relies heavily on CSDs and investment firms to develop their own proprietary platforms. A complete exclusion would also cast an inconvenient shadow of legal uncertainty on to STOs completed via public blockchains. Testament to the fast evolutionary pace of the new digital marketplace, the Digital Finance Package hardly recognises predominant trends within Decentralised Finance space. ${ }^{130}$

This article has aimed to show that the evolution of DLT systems has not outdated the fundamental objectives of securities law harmonisation, i.e., ensuring effective protection of investor rights, preserving the integrity of the holding system, and ensuring mutual compatibility of legal systems. ${ }^{131}$ Failing to act would risk magnifying the unresolved legal risks of intermediated securities and further fragmenting the private law underpinnings of EU capital markets. As a first step, the EU should exploit the opportunity to adopt a common approach, at least to protect security token holders in the insolvency of a DLT market infrastructure provider (or a participant). However, a functional minimum harmonisation approach would not work for conflict-of-laws rules where uniformity and predicta-

129 For an excellent discussion on alternative convergence strategies in the context of secured credit laws, see Teemu Juutilainen, Secured credit in Europe: from conflicts to compatibility, 2018.

130 Emilios Avgouleas/Aggelos Kiayias, "The Architecture of Decentralised Finance Platforms: A New Open Finance Paradigm”, Edinburgh School of Law Research Paper No. 2020/16, available at: http://dx.doi.org/10.2139/ssrn.3666029 accessed 4 March 2021.

131 Thévenoz (fn. 80), intro, p. 17. 
bility are needed. To choose the right rule, policy-makers must assess various trade-offs in terms of legal certainty, market integration, competition, and efficiency. To support market integration and internationalisation, the article suggested maintaining a PRIMA-type of rule as an alternative.

Going further, DLT-powered securities holding systems are likely to offer wider participation rights and more convenient (and hopefully cheaper) investor segregation for all market participants, retail and institutional alike. Nevertheless, the intermediated securities holding system continues to offer benefits with respect, e.g., to legal risk management, securities financing, diversification and portfolio collateralisation - which will be hard to replicate in a pure direct holding system. In developing a legal framework for holding systems that integrate investor choice and flexibility with end-investor transparency, useful lessons could be drawn from the mixed holding systems currently hosted by the Nordic countries. 